\title{
Service Learning Programs with Juvenile Offenders
}

\author{
Mark Dickerson ${ }^{1}$, Randy Fall ${ }^{1} \&$ Roxanne Helm-Stevens ${ }^{1}$ \\ ${ }^{1}$ School of Business and Management, Azusa Pacific University, California, USA \\ Correspondence: Roxanne Helm-Stevens, School of Business and Management, Azusa Pacific University, \\ California, USA. Tel: 1-626-815-6000. E-mail: rhelmstevens@apu.edu
}

Received: September 5, 2019

doi:10.5539/ies.v13n2p88

\author{
Accepted: October 7, $2019 \quad$ Online Published: January 29, 2020 \\ URL: https://doi.org/10.5539/ies.v13n2p88
}

\begin{abstract}
While prior research on service-learning has established the benefits for participating college and university students, more recent research has attempted to explore the value of service-learning projects for the recipients of the service-learning projects, typically public-school students. This study endeavors to extend this research to a special subset of this population by examining the outcome of a 6-week service-learning project in an alternative educational setting for juvenile offenders.

This service-learning project involved teams of four to five university business school students presenting a life skills curriculum to two classrooms of students who have been adjudicated through the juvenile courts. We administered an optional questionnaire to all participating students as a pretest and posttest, asking about their knowledge and skills in career readiness. We found statistically significant increases in ratings from pretest to posttest. Analyzed individually, all 28 items showed statistically significant improvements from pretest to posttest. Scales created from the items were also statistically significant, with the greatest change in items measuring Goals. We interpret these findings as an indication that adjudicated youth have a substantial need and interest in career information and training.
\end{abstract}

Keywords: juvenile offenders, service-learning, career readiness

\section{Introduction}

Research suggests that certain at-risk student populations assigned to nontraditional academic settings feel more comfortable and are, therefore, more motivated to attend school. As specialized educational environments, alternative high schools provide higher levels of teacher interaction and environments geared to the special needs of this population (Hawkins \& Wall, 1980; Raywid, 1983). According to Ingersoll and Leboeuf (1997), the goal is to provide educational instruction to students that are often unable to succeed in traditional academic settings. Consequently, such schools are being used to teach juvenile offenders (Gottfredson, 1987; Arnove \& Strout, 1980). According to the Office of Juvenile Justice and Delinquency Prevention (2001), often such schools are able to achieve the twin aims of segregating disruptive students from classrooms as well as holding the youth responsible for their actions.

The number of juvenile offenders who may benefit from specialized educational environments and teaching methodologies is significant. According to the Federal Bureau of Investigation (2017), over 680,000 juveniles were arrested in 2016 and according to the National Center for Juvenile Justice; juvenile courts processed approximately 850,000 cases (Hockenberry \& Puzzanchera, 2018). As a response to the complex issues surrounding juvenile justice issues, the Juvenile Offenders and Victims: 2014 National Report notes "the juvenile justice system must react to the law-violating behaviors of youth in a manner that not only protects the community and holds youth accountable but also enhances youth's ability to live productively and responsibly in the community" (Sickmund \& Puzzanchera, 2014, p. 3). Hence the need to develop an array of pedagogical approaches to serve this population, including skills relevant to future employment.

While alternative schools vary in their programming and approach, there is minimal research into the benefits provided by service learning, if any, to the communities of at-risk juvenile youth and offenders. Furthermore, research on the benefits of service-learning programs involving at-risk youth, such as low-income or delinquent youth, is scant. 


\section{Literature Review}

Abundant evidence supports the proposition that service learning in colleges and universities has the potential for providing transformational learning experiences to participating college and university students. Leveraging the power of experiential education, critical reflection and direct engagement with community needs, service learning is seen as a powerful tool for integrated learning by college students (Beatty, 2010; Jacoby, 1996). The Clearinghouse at National Youth Service Council (2016) describes service learning as "a teaching and learning strategy that integrates meaningful community service with instruction and reflection to enrich the learning experience, teach civic responsibility and strengthen communities" (https://gsn.nylc.org/clearinghouse).

Programs employing a service learning approach have witnessed positive results for growth in interpersonal communication skills and other leadership behaviors (Foli, et al., 2014), and in some cases, a sense of calling (Park, 2009; Dickerson, et al., 2017). Moreover, such courses have "been determined to positively impact a variety of academic and nonacademic outcomes, including writing skills, critical thinking and problem-solving skills, interpersonal skills, leadership abilities and commitment to activism and civic responsibility" (Arthur \& Valentine, 2018, p. 1; see also Moely \& Ilustra, 2014; A. Astin \& H. Astin, 2000; Astin et al., 2000).

While more recent research also describes the benefits of service learning to community organizations and the characteristics of successful of university-nonprofit service learning partnerships, the program benefits for community participants received scant attention until recently (Cruz \& Giles, 2000; Tryon \& Stoecker, 2009, etc.). However, beginning in the late 1990 's, researchers turned to discovering how service learning programs impact community participants and not just the community organizations involved (Gray, et al., 2000; Schmidt \& Robby, 2002; Helm-Stevens, Dickerson \& Fall, 2019; Helm-Stevens, et al, 2014).

\subsection{Critical Service Learning Philosophy Applied to Service Learning with Juvenile Offenders}

At about the same time, scholars began reporting on service learning programs involving youth and young adult offenders adjudicated through the courts (Davidson et al., 2010; Hinck et al., 2013; Tilton, 2013; Gould et al., 2015; Arthur \& Valentine, 2018). In contrast to traditional service learning programs, these service learning efforts are founded on a critical service learning philosophy which frames service learning as a mechanism for students to reconsider their assumptions and perception of the "other" as well as critical reflection regarding the deeper social structures that create the social justice issues faced by those individuals (Mitchell, 2008; Gruenewald, 2003). Hinck et al. (2013) explain that “...firsthand experience [inside detention institutions] can become an important way to shape an audience's sensitivity for processing arguments calling for social change regarding the prison-industrial complex ... and prepare the public for a critical examination of incarceration policy ..." (p. 40).

In addition to the benefits to college students engaged in critical service learning programs behind bars, a number of observers have contended that higher education programs in prisons prepare inmates for successful transitions back into society and advocate for a participatory model of collaboration between educators and correctional officials (see, e.g., Gould et al., 2015). Further, researchers suggest that service learning programs including both college students and inmates may reduce recidivism in juvenile and young adult offenders by transforming their identity from criminals to law-abiding citizens who have paid the price for their offenses, pointing to studies of the benefits of prison vocational training and post-secondary programs (Fox, 2016; Hinck et al., 2013; Lagemann, 2016; see also, Clinkinbeard \& Zohra, 2012).

\subsection{Empirical Studies of Service Learning with Juvenile Offenders}

Three significant studies examining the effect of service learning on juvenile and young adult offenders have been conducted by Hinck et al. (2013), Davidson et al. (2010) and Arthur and Valentine (2018).

Hinck et al. (2013) describe two service learning programs conducted by a university at correctional facilities in Michigan. The first program examined involved 133 undergraduate and graduate students who interacted with incarcerated young adults, either through judging a debate/speech competition or by conducting a public speaking workshop. Researchers found that college students' perceptions of prisoners became significantly more positive, improved their understanding of concepts learned in speech class, increased their acceptance of the proposition that increasing prisoners' skills improve their chances for becoming productive members of the community, and made them more likely to volunteer after the service learning class was completed. The second study involved between 15 and 18 graduate students who worked on either interpersonal communication skills or public speaking skills with inmates. Students in this program also developed positive attitudes toward prisoners and reported that they believed the program had a beneficial impact on the prisoners.

Davidson et al. (2010) describes the Michigan State University Adolescent Diversion Project (“ADP”), its 
history, and a qualitative study with ADP students. The program partnered MSU undergraduate students in a service learning course who were trained in and delivered a hybrid of child advocacy and behavioral interventions with juveniles referred by the Intake Division of the Juvenile Court rather than process them through standard sentencing protocols. Young adults participating in ADP experienced recidivism rates half of those youth who were managed through usual treatment or release programs and attended school at a $63 \%$ rate compared to a $26 \%$ rate for youth in the control group. Further, the program reduced community expenditures on delinquent youth and allowed the courts to focus their resources more efficiently.

The qualitative study of ADP involved systematic interviews with 12 undergraduate students who had participated in the ADP for the past two semesters. The students were asked to reflect on what the course had taught them about themselves and society. While individual student responses varied, in general they noted that they had been personally transformed, learning new competencies and becoming more knowledgeable citizens. They also increased their awareness of challenges within the social system, including social inequality, the difficulties in acting as a change agent, and the different ways of understanding the situation when intervening in a situation.

In another paper by Arthur and Valentine (2018), the authors describe their qualitative study of two service-learning programs at Portland State University. The first program involved small groups of PSU students engaging in a writing and art workshop with juveniles between ages 12 and 18 held in a detention center. The program describes itself as providing youth with opportunities for self-expression. During this program, both college students and juveniles reflected on the deep, structural roots that underlay the incarceration of young people. The second program studied brought PSU students into a correctional facility for young adults (most between 16 and 25 years of age). In this program, college students and correctional students jointly studied social justice movements and were required to develop and engage in a civic engagement project.

The authors found that the participating college students developed more positive perceptions of the detained youth and found similarities between themselves and their counterparts. Further they became aware of the power of collaboration and more committed to social justice and advocacy. The incarcerated students renewed their sense of hope in the future, experienced personal transformation, learned to appreciate the power and importance of community and strengthened their commitment to engage in the community.

\subsection{Future Directions in Research}

While these reports of programs involving a "critical" service learning pedagogy are promising, missing from the literature thus far are studies of service learning involving youth caught up in the criminal justice system where there is not a critical service learning pedagogy involved and juveniles are taught basic life skills without a deeper dive into the dynamics that led them to the juvenile justice system or an emphasis on social justice advocacy. This study probes the impact a traditional service learning program can have on secondary students on probation with the juvenile courts.

\section{Service-Learning Project Description}

Organizational and Administrative Behavior, MGMT448, a required, upper-level business management class, contains an intensive, off-site service-learning project as a teaching and learning strategy. Small groups of university students are each assigned a classroom in a continuation high school and prepare and deliver modules focused on such areas as study skills, goal setting, planning for future employment and consumer finance for an hour each week for six weeks.

The curriculum for the course was developed with education and mentorship as core objectives and includes a variety of opportunities for university students to mentor the high school students.

\subsection{Participants}

Nineteen secondary students attending an alternative education high school participated in this project, having been either expelled from their district or involuntarily transferred. When students are referred from their school district, they are usually contracted to attend the alternative education high school pending the completion of their rehabilitation plan. All students are in the juvenile court system, on probation, and assigned a probation officer. Their activities are restricted and they each wear an electronic ankle bracelet to monitor their movements. A large number of students come from single parent households where one or more family members are incarcerated, or are in placement by the courts in local group or foster home. All students have fallen behind the traditional high school timelines and are deficient in subject credits.

Typically, students have attendance issues, safety concerns due to gang involvement, social anxiety issues, and difficulty learning in a traditional educational environment. Incoming students are assessed in academic 
standing, learning modalities, and personality.

The alternative education site where the research was conducted provides two self-contained classrooms where students are placed in small groups of 7 or less based on their temperament and academic ability. In addition to Math, English, History, Science, Art, and Physical Education, vocational classes are offered. Senior high school students are given the opportunity to complete their graduation requirements through credit recovery educational strategies. Graduates are given the opportunity to continue in the post-secondary certificate or technical degree programs. The graduation rate was $51.4 \%$ in 2016 .

\section{Research}

\subsection{Sample}

Nineteen high school students participated in the study. Ages of participants ranged from 13 to 18 , with a mean age of 15.6. Ethnicities reported by participants were 13 Hispanic, 2 African-American and 1 White, with 2 not reported. There were 15 males and 2 females, with 2 not reported.

\subsection{Instrument}

Research data for this study was gathered utilizing a 6-point Likert-scale survey instrument. Pretest surveys were administered in classrooms by the university students, under the supervision of the high-school teachers. Collected one week after the last lesson plan, posttest surveys were administered in classrooms by the high-school teachers.

\section{Results}

Visual inspection of the means and frequencies for the questions reveal remarkable increases in ratings from pretest to posttest. On a 6-point Likert scale, item means ranged from 1.08 to 3.13 on the pretest, while item means ranged from 3.11 to 5.16 on the posttest. Pretest standard deviations ranged from .28 to 1.1. Posttest standard deviations were larger, ranging from 1.1 to 1.92 . The means and standard deviations demonstrate a relatively narrow range of responses to pretest items, with greater dispersion among posttest responses. Mean differences by items ranged from 2.5 to 4.9, on a 6-point scale from Strongly Disagree to Strongly Agree. That is, for several items all students rated a 1 or 2 on the pretest, and rated 5 or 6 on the posttest. Items with mean differences greater than 4 are presented in Table 1 .

All of the posttest means were higher than the corresponding pretest means, presenting a general positive effect of the curriculum and project. Analyzed individually, all 28 items showed statistically significant improvements from pretest to posttest.

We next computed scales combining similar items, resulting in the following scales: self-knowledge, work, goals, skills, resources and attitude. All scales showed statistically significant increases in ratings from pretest to posttest. Paired samples statistics are presented in Table 2.

Taken together, these results indicate very unusually large changes in students' attitudes from pretest to posttest.

Table 1. Items with mean differences greater than 4

\begin{tabular}{lc}
\hline Item & Mean Difference \\
\hline 7. I feel I have an understanding of appropriate business behavior. & 4.5 \\
10. I often plan for the future. & 4.4 \\
11. I have a plan of where I want to be 3-5 years from now. & 4.1 \\
16. I have something that I am passionate about (a class, a sport, a hobby). & 4.1 \\
17. I feel confident about my ability to speak in a public setting. & 4.0 \\
19. I know how to work together with other members of my team during a group project. & 4.4 \\
22. If asked questions about myself during an interview, I would know how to answer. & 4.3 \\
23. For interviews, I believe keeping eye contact/maintaining good posture are important. & 4.9 \\
24. I understand the value of nonverbal communication. & 4.8 \\
\hline
\end{tabular}


Table 2. Paired samples t-tests on clusters

\begin{tabular}{cccccc}
\hline & Mean Difference & Standard Deviation & $\mathrm{t}$ & $\mathrm{df}$ & $\mathrm{p}$ \\
\hline Skills & -23.66667 & 10.65364 & -6.664 & 8 & .000 \\
Resources & -4.40000 & 2.58567 & -6.591 & 14 & .000 \\
Attitude & -10.46154 & 5.22199 & -7.223 & 12 & .000 \\
Goals & -13.53846 & 5.23793 & -9.319 & 12 & .000 \\
Work & -9.38462 & 5.66478 & -5.973 & 12 & .000 \\
\hline
\end{tabular}

\section{Discussion}

The data from this study provides strong evidence that juvenile offenders reported substantial benefit from the service-learning project. For several of the survey items, means from pretest to posttest showed gains of four or more points, a very unusual size of change for a six-point Likert scale. The adjudicated students reported benefits in every domain of the curriculum: skills, resources, attitude, goals and work.

In previous studies, we have reported on similar service-learning interventions with diverse populations from regular public schools (Helm-Stevens, Dickerson, \& Fall, 2019; Helm-Stevens et al., 2014). The comparison of those studies to this data shows a much greater impact reported by the juvenile offenders, both in the magnitude and pervasiveness of the effects. It appears from this data that such youth do not come to school with the skills and knowledge about work expectations and skills that other youth seem to gain from out-of-school environments. This sample of juvenile offenders seem to have benefitted from some training that typical students sometimes find to be natural, or that they have learned in other contexts, like the need to make eye contact during an interview, or the importance of non-verbal communication. It appears that the adjudicated youth had not had the instruction in college and career planning that is typically experienced by other youth, and so found the information in this service-learning project to be novel and encouraging. We speculate that the juvenile offenders had a greater appreciation of the efforts of the university and university students to presume that their future would include careers and future education, rather than antisocial behavior.

The similarity in age of the university students to the juvenile offenders participating in the service learning program appeared to be an important factor in the impact of the intervention. The adjudicated youth appeared to receive the information from the university students more readily than they might have from an adult authority. The substantial benefits reported by these youth should encourage future service-learning intervention and research with this population.

\section{Limitations}

A number of barriers exist in conducting research with youth involved in the juvenile justice system. Not only is it difficult to arrange to interact with large groups of detained youth, such individuals may have issues of learning disabilities, illiteracy and limited language proficiency and their participation in the service learning program may be cut short by the terms of their probation. Further, since the Belmont Report in 1979, restrictions have been place on research studies involving incarcerated individuals as a vulnerable population requiring extra layers of protection (Pont, 2008). Among other issues, prisoners are susceptible to exploitation and unable to grant informed consent freely. As a result, the survey questions in this study were limited to high school student perceptions of the benefits they gained from the program and steered away from sensitive subject matter.

It is important to acknowledge that the magnitude of the changes from pretest to posttest might also reflect students' attitudes or teacher behaviors that could not be controlled by the researchers. Anecdotal reports from the students and teachers indicated that the participating high school students enjoyed the opportunity to interact with the university students, and so we have to allow for the possibility that students may have inflated their posttest scores as a way to show their appreciation for the overall project, as something of a conscious Hawthorne effect. We also could not control teacher behavior before and after our time in the classroom, and it is possible that teachers encouraged students to rate the intervention positively, as a way to encourage future similar engagement.

Other limitations include the small size of the sample surveyed as well as potential issues with participant interpretation of survey questions. The self-reported perceptions of these juveniles may not accurately reflect their learning. Further, no comparison groups were included to support conclusions regarding the program's impact.

Officials at the alternative school determined which class would participate in the service learning program and teachers at the facility gathered data for the study utilizing survey instruments developed by researchers. 
Selection of the participating high school students as well as interactions during the data collection process may have inserted confounding variables into the results.

Finally, a methodology triangulating multiple sources of data may have provided more nuanced results; however, the survey approach used in this study is adequate to meet the exploratory goals of this research.

\section{Recommendations}

Due to the lack of studies examining service-learning projects involving juvenile offenders, a number of possible recommendations for future study exist. Two of the more prominent recommendations include replicating the study and extending the curriculum thereby lengthening interaction time.

This study offers an initial probe into the impact of a service learning program on high school students under custody of the juvenile court system. Replication of the research study may confirm or overturn findings. Similarly, complementary research, such as enhancing the curriculum, may extend the research findings.

\section{Acknowledgements}

This research was supported by Aaron Acosta, Shane Shannon, Kevin Stough, and Orlando Griego.

\section{References}

Arnove, R., \& Strout, T. (1980). Alternative schools for disruptive youth. The Educational Forum, 44(4), 453-471. https://doi.org/10.1080/00131728009336189

Arthur, D. S., \& Valentine, J. (2018). In service together: University students and incarcerated youth collaborate for change. The Prison Journal, 98(4), 427-448. https://doi.org/10.1177/0032885518776377

Astin, A. W., \& Astin, H. S. (2000). Leadership reconsidered: Engaging higher education in social change. Battle Creek, MI: W. K. Kellogg Foundation.

Astin, A. W., Vogelgesang, L. J., Ikeda, E. K., \& Yee, J. A. (2000). How service learning affects students. UNO Digital Commons at UNO. Retrieved from http://digitalcommons.unomaha.edu/cgi/viewcontent.cgi?article $=1145 \&$ context $=$ slcehighered

Beatty, J. E. (2010). For which future? Exploring the implicit futures of service-learning. International Journal of Organizational Analysis, 18(2), 181-197. https://doi.org/10.1108/19348831011046254

Clinkinbeard, S., \& Zohra, T. (2012). Expectations, fears and strategies: Juvenile offender thoughts on a future outside of incarceration. Youth and Society, 44(2), 236-257. https://doi.org/10.1177/0044118X11398365

Criminal Justice Information Services Division, Federal Bureau of Investigation. (2017). 2016 Crime in the United States. Retrieved from https://ucr.fbi.gov/crime-in-the-u.s/2016/crime-in-the-u.s.-2016/cius-2016

Cruz, N. I., \& Giles, D. E. (2000). Where's the community in service-learning research. Michigan Journal of Community Service Learning, 7(1), 28-34.

Davidson, W. S., Jimenez, T. R., Onifade, E., \& Hankins, S. S. (2010). Student experiences of the Adolescent Diversion Project: A community-based exemplar in the pedagogy of service learning. American Journal of Community Psychology, 46, 442-458. https://doi.org/10.1007/s10464-010-9337-6

Dickerson, M. S., Helm-Stevens, R., \& Fall, R. (2017). Service-learning in business education: An analysis of spirituality, leadership and motivation. American Journal of Economics and Business Administration, 9(1), 1-12. https://doi.org/10.3844/ajebasp.2017.1.12

Foli, K. J., Braswell, M., Kirkpatrick, J., \& Lim, E. (2014). Development of leadership behaviors in undergraduate nursing students: A service-learning approach. Nursing education perspectives, 35(2), 76-82. https://doi.org/10.5480/11-578.1

Fox, K. J. (2016). Civic commitment: promoting desistance through community reintegration. Punishment and Society, 18(1), 68-94. https://doi.org/10.1177/1462474515623102

Gottfredson, G. (1987). American education-American delinquency. Today's Delinquent, 6(1), 1-65.

Gould, M., Harkins, G., \& Stevens, K. (2015). College civic engagement and education behind bars: Connecting communities, creating change. In R. Scott (Ed.), Bringing college education into prisons: new directions for community colleges (pp. 101-110). Hoboken, NJ: John Wiley and Sons. https://doi.org/10.1002/cc.20148

Gray, M. J., Ondaatje, E. H., Fricker Jr, R. D., \& Geschwind, S. A. (2000). Assessing Service-Learning: Results Froma a Svervy of "Learn and Serve America, Higher Education". Change: The Magazine of Higher Learning, 32(2), 30-39. https://doi.org/10.1080/00091380009601721 
Gruenewald, D. A. (2003). The best of both worlds: A critical pedagogy of place. Educational Researcher, 32(4), 3-12. https://doi.org/10.3102/0013189X032004003

Hawkins, J., \& Wall, J. (1980). Alternative education: Exploring the delinquency prevention potential. Washington, DC: U.S. Department of Justice, Office of Justice Programs, Office of Juvenile Justice and Delinquency Prevention.

Helm-Stevens, R., Dickerson, M. S., \& Fall, R. (2019). Service-learning as a catalyst for community change: An empirical examination of measuring the benefits of a life skills curriculum in local, at-risk high schools. Business and Management Research, 8(2), 22-29. https://doi.org/10.5430/bmr.v8n1p22

Helm-Stevens, R., Fall, R., Havens, C., \& Polvi, L. (2014). The impact of service-learning curriculum at a local at-risk high school: An examination of preliminary data. American Journal of Economics and Business Administration, 6(3), 132-142. https://doi.org/10.3844/ajebasp.2014.122.132

Hinck, S. S., Hinck, E. A., \& Withers, L. A. (2013). Service-learning in prison facilities: interaction as a source of transformation. In S. J. Hartnett, E. Novek, \& J. K. Wood (Eds.), Working for justice: A handbook of prison education and activism (pp. 39-59). Urbana: University of Illinois Press.

Hockenberry, S., \& Puzzanchera, C. (2018). Juvenile Court Statistics 2016, National Center for Juvenile Justices, Office of Juvenile Justice and Delinquency Prevention. Retrieved from https://www.ojjdp.gov/ojstatbb/njcda/pdf/jcs2016.pdf

Ingersoll, S., \& LeBoeuf, D. (1997). Reaching out to youth out of the education mainstream. Bulletin. Washington, D.C.: U.S. Department of Justice, Office of Justice Programs, Office of Juvenile Justice and Delinquency Prevention. https://doi.org/10.1037/e302462003-001

Jacoby, B. (1996). Securing the future of service-learning in higher education: A mandate for action. In B. Jacoby (Ed.), Service-learning in higher education: Concepts and practices (pp. 317-336). San Francisco, CA: Jossey-Bass.

Lagemann, E. C. (2016). Liberating minds: The case for college in prison. New York, NY: The New Press.

Mitchell, T. D. (2008). Traditional vs. critical service-learning: Engaging the literature to differentiate two models. Michigan Journal of Community Service Learning, 15, 50-65. Retrieved from http://hdl.handle.net/2027/spo.3239521.0014.205

Moely, B. E., \& Ilstra, V. (2014). The impact of service learning course characteristics on university students' learning outcomes. Michigan Journal of Community Service Learning, 21(1), 5-26.

Park, D., Helm, R., Kipley, D., \& Hancock, D. (2009). Connecting faith and personal values with the service learning experience to create more effective service learning. Business Renaissance Quarterly, 4, 61-76.

Pont, J. (2008). Ethics in research involving prisoners. International Journal of Prisoner Health, 4(4), 184-197. https://doi.org/10.1080/17449200802473107

Puzzanchera, C., Adams, B., \& Sickmund, M. (2011). Juvenile Court Statistics 2008, National Center for Juvenile Justice, Office of Juvenile Justice and Delinquency Prevention. Retrieved from http://www.ncjj.org/Publication/Juvenile-Court-Statistics-2008.aspx

Raywid, M. (1983). Alternative schools as a model for public education. Theory Into Practice, 22(3), 190-197. https://doi.org/10.1080/00405848309543060

Schmidt, A., \& Robby, M. A. (2002). What's the value of service-learning to the community? Michigan Journal of Community Service Learning, 9, 27-33. Retrieved from http://hdl.handle.net/2027/spo.3239521.0009.103

Sickmund, M., \& Puzzanchera, C. (2014). Juvenile Offenders and Victims: 2014 National Report. Pittsburgh, PA: National Center for Juvenile Justice.

The Beat Within. (2019). About Us. Retrieved from: http://thebeatwithin.org/about-us/

Tilton, J. (2013). Rethinking youth voice and institutional power. Reflections from inside a service learning partnership in a California juvenile hall. Children and Youth Service Review, 35, 1189-1196. https://doi.org/10.1016/j.childyouth.2013.02.015

Tryon, E. \& Stoecker, R. (2009). The unheard voices: Community organizations and service learning. Philadelphia, PA: Temple University Press. 


\section{Copyrights}

Copyright for this article is retained by the author(s), with first publication rights granted to the journal.

This is an open-access article distributed under the terms and conditions of the Creative Commons Attribution license (http://creativecommons.org/licenses/by/4.0/). 